\title{
A Study of Architecture of Thin Interlayer within Meandering River Monosandbody of Thick-Bedded Oil Layers
}

\author{
Jingfu Shan ${ }^{1,2}$, Zhipeng Lin $^{1,2}$, Le Chen ${ }^{1,2}$, Bo Liu ${ }^{1,2}$, Wei Fang ${ }^{1,2}$, Le Zhang ${ }^{1,2} \&$ Lili Xie ${ }^{1,2}$ \\ ${ }^{1}$ Key Laboratory of Exploration Technologies for Oil and Gas Resources, MOE, Yangtze University, Hubei Wuhan \\ 430100, China \\ ${ }^{2}$ School of Geosciences, Yangtze University, Hubei Wuhan 430100, China \\ Correspondence: Jingfu Shan, School of Geosciences, Yangtze University, Caidian, Wuhan, China. Tel: 86-139- \\ 7210-2588. E-mail: shanjingfu2003@163.com
}

Received: June 20, 2017

Accepted: July 14, 2017

Online Published: July 20, 2017

doi:10.5539/jgg.v9n3p16

URL: http://dx.doi.org/10.5539/jgg.v9n3p16

\begin{abstract}
This paper investigates the reservoir architecture of thin interlayer within meandering river monosandbody in the thick-bedded oil layers. The thin interlayer within the monosandbody of the terrestrial reservoir is one of the dominant factors which form the reservoir heterogeneity of fluid motion. It is of equal importance in comparison with the rhythmic distribution of permeability, and it is also the important content of the elaborate representation of reservoirs. However, previous researches of the heterogeneity of reservoir focus mostly on the theory of distribution disparity of the permeability and neglect the influence of thin interlayer on the heterogeneity. Therefore, taking the PI2 individual reservoir at the Putaohua reservoir formation in Daqing oilfield as an example, this paper analyzes the distribution, formation, and the three-dimensional construction of the internal thin interlayer of the monosandbody from a new point of view, on the basis of which a set of cycle research technique about it is put forward. With the method of configuration parameter extraction, which is most important before establishing interlayer configuration in three dimensions, this study clarifies the classification, causes of formation and the differences of distinct monosandbodies. Ultimately, four categories of thin interlayer according to the characteristics of the studied area is divided and two dominate causes for thin interlayer formation is discussed: argillaceous and arenaceous rock interlayer through deposition and interlayer in process of sedimentary diagenesis.For the convenience of the study, here mainly focuses on the thick - thin interlayer. Techniques are taken the use of determining the obliquity of the thin interlayer superface based on the configuration of paired wells and abandoned channel surface. The causes for thin interlayer and their classification, distribution and the three-dimensional construction are entirely revealed, which would possess important geologic meaning for taking affective engineering measures in the aspects of the elaborate representation of oil reservoir, and the research of remaining oil formation and distribution.
\end{abstract}

Keywords: monosandbody, thin interlayer, architecture, parameter of meandering river; Putaohua reservoir, Daqing oilfield

\section{Introduction}

Along with profound exploration and exploitation (Figure 1), the oilfield at the No.1 area Yaojia formation reservoir in Daqing has come into the ultra-high water-containing phase(Fan \& Ma, 2011; Ma et al., 2015; Lin, Shan, \& Chen, 2017b; Yang et al., 2017). Therefore, hunting for remaining oil, enhancing oil and gas output to attain the full potential are urgent problems to be solved. 


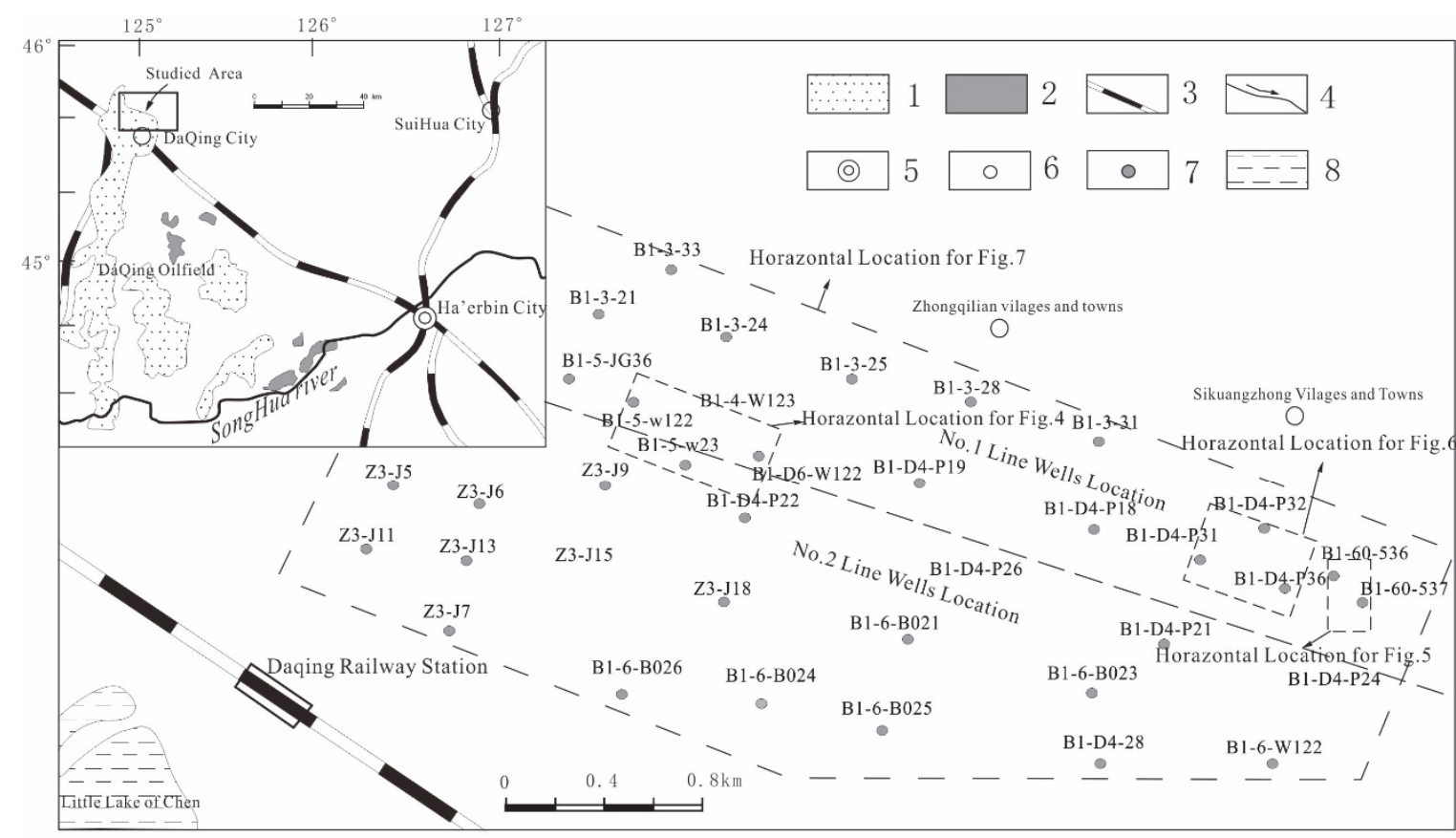

1.Oiliness Structure 2.Gassiness Structure 3.Railway Station 4.Stream 5.Province

6.Vilages, Towns and City 7.Wells Location 8.Swampland

Figure 1. The geographic position diagram of the studied area

In the initial and middle stages of oilfield development, researches on oil layer particularly emphasize the distribution, scale, connectedness and macro-heterogeneous of monosandbody, which plays an important part in the layout of the well network and oil-water dynamic and so on. But in the high water-containing and the third exploitation stage, because of lasting exploitation of oil layer, more and more distinct intraformational discrepancy brings great influence on the injection-fluid agent oil-displacing and remaining oil formation and distribution in the monosandbody(Dutton et al., 2005; Singh, Bijeljic, \& Blunt, 2016), particularly on the meandering channel sandbody whose heterogeneity is serious in the high water-containing stage and the third exploitation phase of oil layer(Wang \& He, 1995; Zhang \& Zhang, 2003; Ru, He, \& Zhou, 2016; Zhao et al., 2016). Formerly, many types of research and analyses of reservoir heterogeneous and remaining oil distribution focused on the properties of matter distribution discrepancy(Zhong \& Zhu, 2008; Shan, Li, et al., 2015; Shan, Zhang, et al., 2015). But, two problems remain unsolved. The first is how to exactly explain fluid seepage mechanism which depends on properties of matter parameter(Morad, Al-Ramadan, Ketzer, \& De Ros, 2010; Bjørlykke, 2014, 2015; Liu, Zhang, Mao, Liu, \& Lü, 2017), and the other, which is more important, is that the research tends to lose sight of the influence of the thin interlayer in the monosandbody on the injection-fluid agent oil-displacing, and the genetic mechanisms for the thin interlayer and their distribution(Li \& Luo, 2011; Cui, Li, Feng, Liu, \& Ju, 2013). The thin interlayer is comparatively non-infiltrative layers unstably distributed in sandstone, which can prevent or control fluid running. Through the practice of oilfield, the thin interlayer in the reservoir plays an important role in fluid seepage of each layer(Wang, Xu, \& Zhong, 2010; Miall, 2014; Lin, 2017; Lin, Shan, \& Chen, 2017a; Matapour \& Karlsen, 2017).

\section{Geology Setting}

Songliao basin is a Mesozoic-Neozoic downfaulted-depression basin, the Cretaceous strata of which alone get to more than 5000m thick(Li \& Liang, 2002; Fu, Lyu, \& Fu, 2003; Hu et al., 2005; Ye, 2005). The Putaohua oil layer of No.1 and 2 line wells in the north part of Daqing Sa'ertu oilfield belongs to the depositional system of Yaojia formation member1 of Songliao basin in upper Cretaceous series, which is located in the north of Sazhong development zone, and totals to $8.9 \mathrm{~km}^{2}$. Through the observation, description and depositional analysis of the eleven coring holes of PI2 individual reservoir at the Putaohua reservoir formation in Daqing oilfield, we find that meandering channel micro-facies generally develop at the individual reservoir, which can be further divided into PI2a snaking stream (Figure 2b) and PI2b winding stream (Figure 2a) sublevel micro-facies(Figure 3). The snaking stream refers to the stream of channel camber index as $1.57 \sim 2.57$, this kind of stream energy is huge, and lateral 
transference range is most extensive. Averagely PI2 individual reservoir thickness is $5.8 \mathrm{~m}$, sandstone thickness is $4.8 \mathrm{~m}$, and the probability of well penetration with more than $3 \mathrm{~m}$ thickness sandstone reaches $78.7 \%$. (A single oil layer regarded as a unit, probability of penetration is the ratio of the wells which penetrate the layer to the total well number in the oil reservoir, and it is used to account for a kind of index of oil reservoir distributing stabilization.)

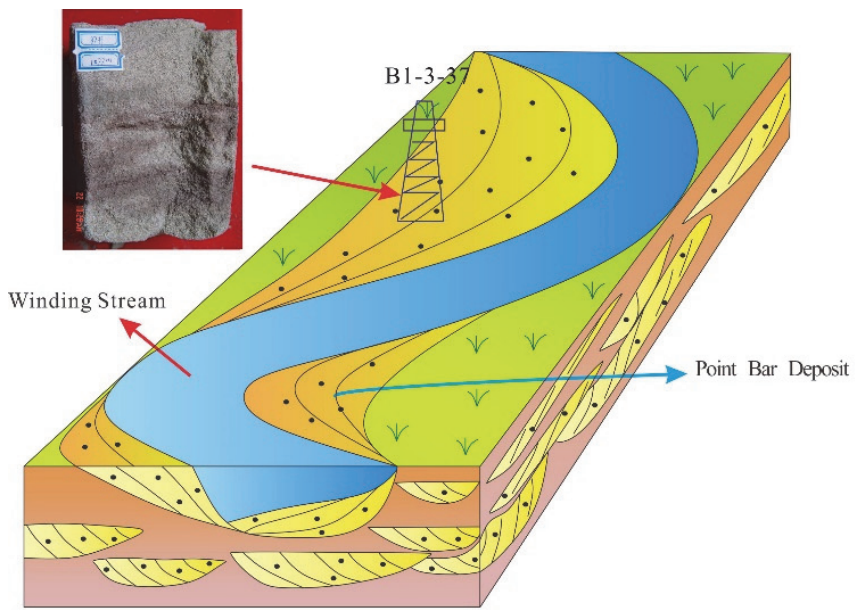

(a) The Winding Channel

$\because$ Channel Sandody $\square$ Meandering Channel
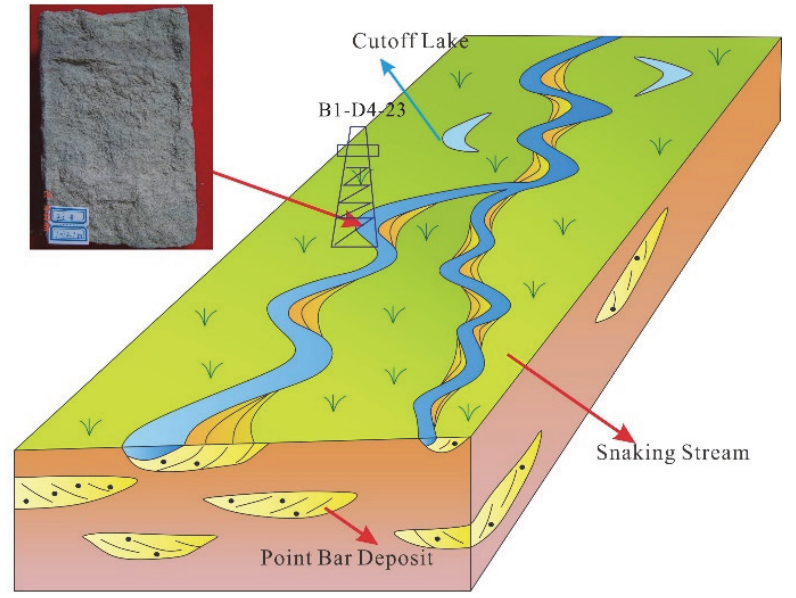

(b) The Snaking Channel

Figure 2. A model for the meandering river with various degree of curve, (a) is the model of winding stream, which can be used to descript the meandering channel microfacies of P I 2b; whilst the (b) is the model of snaking stream, which can be used to descript the meandering channel microfacies of P I 2a (modified after Yan Zhang, 2004)

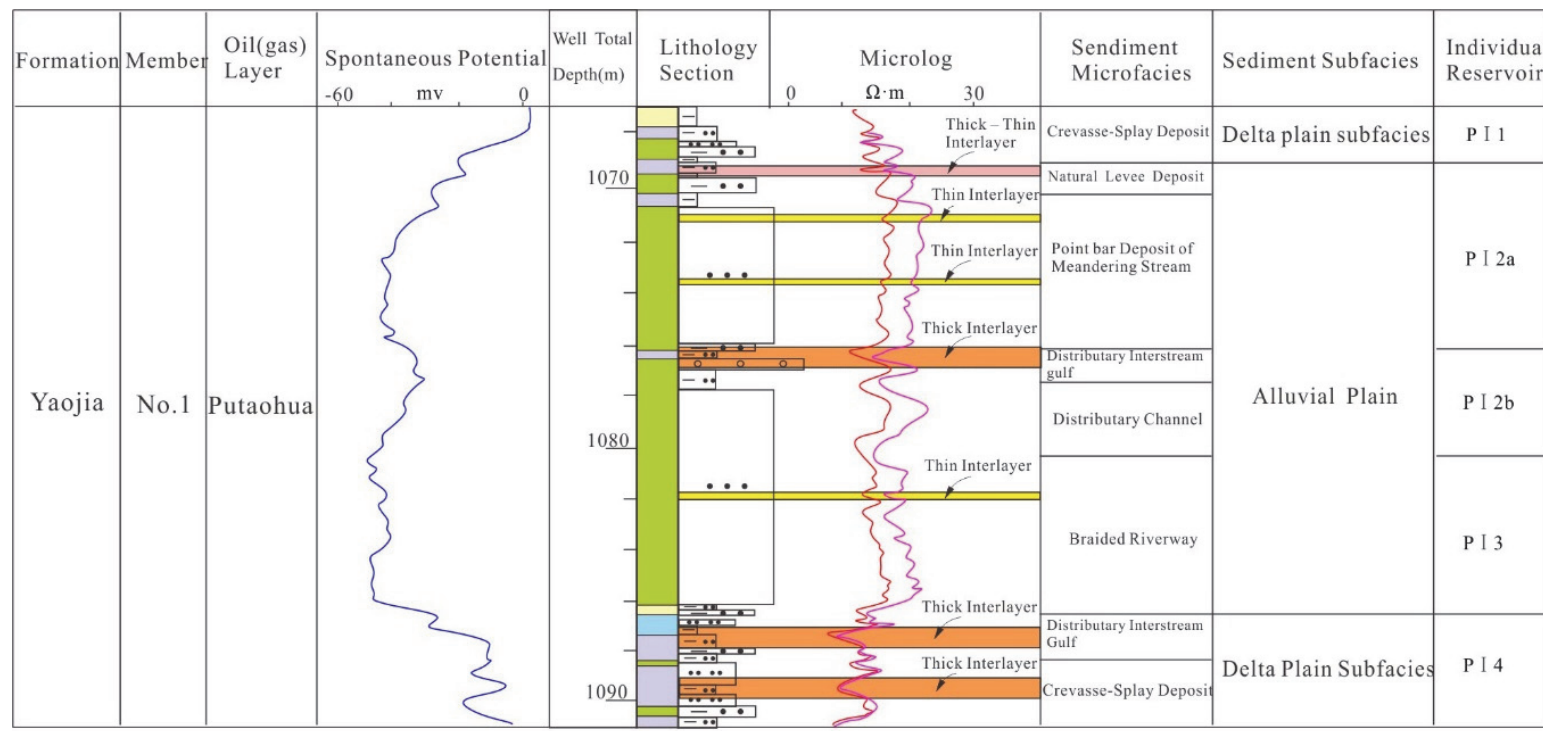

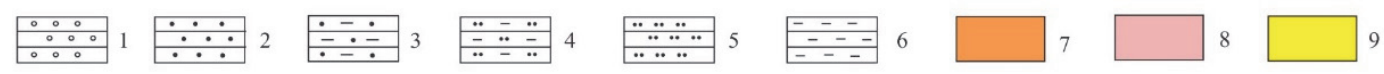

1. Basal Conglomerate 2. Sandstone 3. Argillaceous Sandstone 4. Argillaceous Siltstone 5. Siltstone 6. Mudstone

7. Thick Interlayer 8. Thick-Thin Interlayer 9. Thin Interlayer

Figure 3. The strata columnar section and sedimentary micro-facies subdividing at Putaohua reservoir formation of the first member Yaojia formation stratum

In the target strata, the probability of channel: sandbody penetration is $80.69 \%$, non-channel sandbody penetration 
$13.93 \%$, and interstream mudstone penetration $5.38 \%$. On the plane, a wide complex meandering channel sandbody is formed through lateral erosion and lateral deposition in repeated migration and superposition of meandering river, because of which the connectivity becomes poor and the sandbody is made up of positive rhythmical multi-superposition vertically. For example, through observing the core from the B1-D4-23 well in PI2a individual reservoir, the snaking channel sandbody is discovered (Figure 2b). The camber index of winding stream channel is $1.21 \sim 1.57$, the stream energy is median, and the lateral migration scope is restricted. PI $2 \mathrm{~b}$ individual reservoir sandstone thickness is $2.1 \sim 6.2 \mathrm{~m}$, and the average is $2.5 \mathrm{~m}$, in which the probability of penetration of channel sandbody is $68.35 \%$, the probability of penetration of non-channel sandbody is $16.14 \%$, and the probability penetration of interstream mudstone is $15.51 \%$. For example, through observing the core from the B1-3-37 well in PI2b individual reservoir, the winding channel sandbody is discovered (Figure 2a)(Zhang, Yin, Yu, Ye, \& Du, 2013; Shan, Zhang, et al., 2015).

\section{Research Methods}

Previous researchers mainly identified monosandbody from the perspective of the plane sedimentary microfacies in the time unit, researched heterogeneous and remaining oil distribution from the perspective of the plane and information (individual rhythmical reservoir), and had acquaintance with monosandbody's plane distribution in the initial and intermediate phase. But, along with water-containing heightening, the intraformational bath and remaining distribution are more and more complex. Hence, a trial study of the three-dimensional configuration of the thin interlayer and its influence on remaining oil distribution is carried out in our research from two aspects.

Table 1. Classification and the features of the thin interlayer

\begin{tabular}{|c|c|c|c|c|c|c|}
\hline \multicolumn{2}{|c|}{ Characteristics } & $\begin{array}{c}\text { Sediment } \\
\text { Microfacies }\end{array}$ & Identification & Thickness $(\mathrm{cm})$ & $\begin{array}{c}\text { Plane } \\
\text { Broadening }\end{array}$ & Lithology \\
\hline \multirow{4}{*}{ 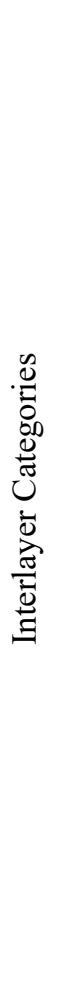 } & $\begin{array}{l}\text { thick } \\
\text { interlayer }\end{array}$ & $\begin{array}{l}\text { fine-grained sheet } \\
\text { deposit, channel } \\
\text { lag deposit and } \\
\text { argillaceous rocks } \\
\text { due to abandoned } \\
\text { channel }\end{array}$ & $\begin{array}{l}\text { basal lag } \\
\text { conglomerate, } \\
\text { partial incision } \\
\text { and filling } \\
\text { deposit }\end{array}$ & mostly $>50$ & $\begin{array}{l}\text { large-scale, } \\
\text { stable several } \\
\text { hundred } ~ \\
\text { several } \\
\text { thousand } \\
\text { meters }\end{array}$ & $\begin{array}{l}\text { mudstone, } \\
\text { argillaceous } \\
\text { siltstone, silty } \\
\text { mudstone, } \\
\text { argillaceous } \\
\text { conglomerate } \\
\text { and calciferous } \\
\text { siltstone }\end{array}$ \\
\hline & $\begin{array}{l}\text { thick } \\
\text { thin } \\
\text { interlayer }\end{array}$ & $\begin{array}{l}\text { brief flooding } \\
\text { diapause deposit, } \\
\text { peak period fine- } \\
\text { grained deposit of } \\
\text { channel }\end{array}$ & $\begin{array}{l}\text { apparent basal } \\
\text { channel } \\
\text { scouring } \\
\text { surface }\end{array}$ & 20 & $\begin{array}{l}\text { small scale, } \\
\text { stable ten } \sim \\
\text { several } \\
\text { hundred } \\
\text { meter }\end{array}$ & $\begin{array}{l}\text { mudstone, silty } \\
\text { mudstone, } \\
\text { argillaceous } \\
\text { siltstone }\end{array}$ \\
\hline & $\begin{array}{l}\text { thin } \\
\text { interlayer }\end{array}$ & $\begin{array}{l}\text { sub-flood peak } \\
\text { deposit or } \\
\text { different } \\
\text { hydrodynamic } \\
\text { force deposit due } \\
\text { to large-scale } \\
\text { flooding }\end{array}$ & $\begin{array}{l}\text { mini type basal } \\
\text { channel } \\
\text { scouring } \\
\text { surface }\end{array}$ & mostly $<5$ & $\begin{array}{l}\text { unstable, } \\
\text { meters } \sim \text { tens } \\
\text { of meters }\end{array}$ & $\begin{array}{l}\text { mudstone, silty } \\
\text { mudstone, } \\
\text { argillaceous } \\
\text { siltstone }\end{array}$ \\
\hline & $\begin{array}{l}\text { the } \\
\text { extremely } \\
\text { thin } \\
\text { interlayer }\end{array}$ & $\begin{array}{l}\text { change of current } \\
\text { condition and } \\
\text { direction, no } \\
\text { apparent hiatus }\end{array}$ & $\begin{array}{l}\text { the interface of } \\
\text { cross bedding } \\
\text { formation }\end{array}$ & $\mathrm{m}$ & $\begin{array}{l}\text { unstable, less } \\
\text { than meters }\end{array}$ & $\begin{array}{l}\text { mudstone, silty } \\
\text { mudstone, } \\
\text { argillaceous } \\
\text { siltstone }\end{array}$ \\
\hline
\end{tabular}

Before studying thin interlayer architecture, the classification, causes of formation and the differences of distinct monosandbodies should be clarified. The monosandbody is the accretion body which consists of single different accretions by repetitious flooding affairs. Every aggradation body possesses definite lithofacies and properties of matter, and it is also an important unit of controlling the characteristics of the inner channel. According to the fine observation of coring well, description, sedimentary analysis, and systemic research of thin intraformational interlayer, the interlayer are divided into four categories, two causes and five kinds of rock combination. 


\subsection{Categories of Thin Interlayer}

To explain the causes and characteristics of configuration, the interlayer is classified according to the structure of sandbody. It is the basis and premise of the research of configuration of the thin interlayer and remaining oil distribution, and the thin interlayer is divided into four categories according to the characteristics of the studied area (Table 1): thick interlayer, thick - thin interlayer, thin interlayer, extremely thin interlayer.

\subsection{Causes for Thin Interlayer Formation}

There are two causes for thin interlayer formation(Geehan et al., 1986; Xue, 1991; Mackey \& Bridge, 1995). One is the interlayer at the stages of deposition including argillaceous interlayer and argillaceous cementation conglomerate interlayer, and the other is the interlayer in process of sediment diagenesis which is mainly calcareous cementation gritstone interlayer. The P I 2 individual reservoir of the studied area is located in the large lake basin of the fluvial-delta sedimentary system. With priority to the meandering channel facies and combining with the causes and development of stream, the characteristics are as follows (Figure 4).

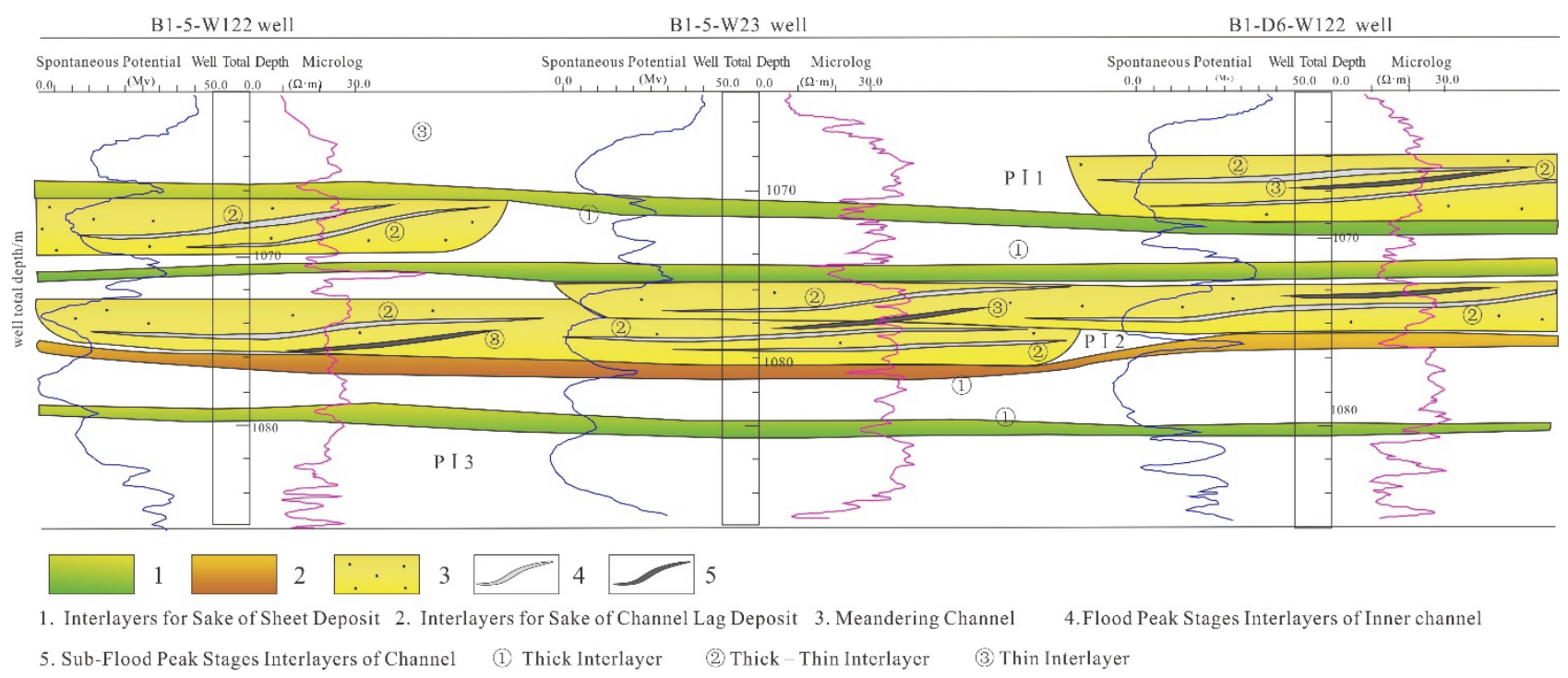

Figure 4. The classification and spatial distribution of the thin interlayers of the meander point bar, which can be seen that the are commonly three kinds of categories of the interlayer could be relatively distinguished from the underground reservoir; while the fourth one- "extremely thin interlayer"- could only be seen figured out through cores data

\section{1) Argillaceous and arenaceous rock interlayer through deposition}

The frequency of interlayer distribution reaches $90 \%$ on the vertical, and the sediment environment types of the interlayer are as follows.

a. Transient flooding diapause deposition. After large-scale flood period, fine-grained seston in the channel (mudstone, silty mudstone and argillaceous siltstone and so on) deposits in the lateral accretion of monosandbody or on top of vertical accretion. It belongs to thick - thin interlayer.b. Fine-grained at the peak period of flooding. At each stage, because water body rapidly becomes deep and water body energy rapidly fails in, sediment mainly contains fine-grained deposit, which is mostly located in the lateral accretion of a meandering river or vertical accretion of the straight river. It belongs to thick - thin interlayer.

c. Fine- grained deposition due to sheetflood. The kind of interlayer is made up of mudstone, argillaceous siltstone and silty mudstone which are caused by the deposition of hydro-distributary channel overflow from levee or underwater distributary channel cross flow. It belongs to the thick interlayer.

d. Cause of abandoned channel. When the energy of stream fades out at each abandoned channel stage, mudstone, argillaceous siltstone and silty mudstone and so on deposit on a large scale, and the mudstone of abandoned channel superface is comparted from the sandstone of channel bottom apparently. It belongs to the thick interlayer.

e. Nagelfluh deposition due to strong hydrodynamic force erosion. Strong hydrodynamic force erosion schleps a great deal of nagelfluh deposit and forms impermeability or ultra-low permeability layer, which appears at the 
bottom of the channel, lateral/vertical accretion, hyperplasia body, and layer-system-formation. The scale and permeability are greatly different in three-dimensional space. It belongs to the thick interlayer.

f. Channel lag deposition. On account of the shearing action of bed home and channel current, hydrodynamic force is slack locally, separating ability drops, and the coarse grain jumbles with the fine-grained. The melange forms an impermeable layer, which is generally located at the bottom of the channel. It belongs to the thick interlayer.

g. Fine-grained deposit of single lateral accretion in the channel during the sub-flooding peak. Aiming at the point bar of a meandering river, the interlayer is formed during the sub-flooding peak, and the scale is small. It generally belongs to the thin interlayer.

h. Fine-grained transient deposit in the channel during the sub-flooding peak. Mainly occurs in the interface of cross-bedding. Because of the small size, it usually can only be seen in the core. It generally belongs to the extremely thin interlayer.

2) Interlayer in process of sedimentary diagenesis

The interlayer formed through diagenesis are made up of impermeable interlayer from calcareous strata or supper impermeable interlayer, which are generally located on the top or the bottom of the channel sandstone, but only the minority is located at the edge of channel(Le \& Wang, 2002; Fu \& Wang, 2008; Li \& Luo, 2011). Calcareous interlayer is mainly formed in two ways. First, the calcareous interlayer deposition by the evaporation of pore water or the deaeration of $\mathrm{CO}_{2}$. in the environment of surface atmosphere and freshwater. In the humid area, pore water vertically infiltrates, which is in favor of deposition and cementation below. But in arid area, strong evaporation raises pore water, which results in calcareous junction layer on the earth's surface. Second, in process of sedimentary diagenesis, along with depth increasing which results in the temperature increasing and pressure build-up, the organic thermal evolution will release plenty of $\mathrm{CO}_{2}$, which will be combined with a $\mathrm{Ca}^{2+} 、 \mathrm{Mg}^{2+}$ ion of reservoir water to form density interlayer of carbonate cementation.

\subsection{Rock Combination of Thin Interlayer}

The thin interlayer comes down to 4 kinds of rock combination(Ma, 1992; Zhao, 2002; Gibling, 2006; Wu \& Yue, 2008), which are as follows.

1) Mudstone interlayer

Mudstone interlayer are made up of mudstone (including silt pelite and silty mudstone) as massive mudstone facies, horizontal bedding mudstone facies, wavy bedding mudstone (silty mudstone) facies and mini type cross-bedding mudstone (silty mudstone) facies, which mainly come from (underwater) distributary channel, abandoned channel or suspension deposition at post-flood stages.

2) Siltstone interlayer

Siltstone interlayer is made up of pelitic siltstone, transitional lithology (mud-bearing siltstone) and so on, which come from (underwater) distributary channel, abandoned channel, suspension deposition at post-flood stages or fine-grained of the channel during flood peak and so on.

3) Nagelfluh interlayer

The nagelfluh interlayer is made up of nagelfluh and sandstone and so on, which come from the bottom gravel due to the strong erosion of hydrodynamic force.

4) Calcareous rock interlayer

Calcareous rock interlayer is made up of calcareous sandstone, calcium-bearing sandstone and so on, which are formed through diagenesis.

In this way, the interlayer from fluvial-delta sedimentary system is mainly formed through deposition and diagenesis. The overwhelming majority of the interlayer formed through deposition, which strictly controls architecture and three-dimensional distribution.

Besides, asphalt interlayer is occasionally found, which are mainly due to crude oil oxidation.

\section{Architecture Techniques}

\subsection{Configuration Parameter Extraction of Lateral Accretion Thin Interlayer in Monosandbody}

The configuration parameter extraction is most pivotal before establishing interlayer configuration in three dimensions. Because the research is not only limited by the studied area data but also restricted by the disparity of interlayer distribution below, the data need to be adjusted to reduce the error. For the convenience of research, this paper mainly focuses on the thick - thin interlayer. The interlayer is researched in the aggradation from 
monosandbody(Fu et al., 2003; Labourdette \& Jones, 2007; Donselaar \& Overeem, 2008). Many methods have been proposed to extract parameters(MacDonald \& Halland, 1993; Lyu, Ma, \& Tian, 1994; Li, 1996; Liu, Yang, \& Yang, 2004; Fabuel-Perez, Hodgetts, \& Redfern, 2009; Wu, Hou, Wang, Cui, \& Shuqing., 2014), and our research focuses on the technique for determining the obliquity of the thin interlayer superface based on the configuration of paired wells and abandoned channel surface.

\subsubsection{Grading Interface of Point Bar}

According to the configuration theories of Mail(1988), which divides the interface of point bar sandstone into the following 5 grades:

No.1 grade interface: It is cross-bedding and does not suffer erosion apparently, which stands for a series of identical continual bottom deposit. The horizontal seepage is rapid, but the vertical seepage is slow.

No. 2 grade interface: It is cross-bedding interface which is similar to No.4 grade interface, but the scale is smaller and there is no evident hiatus. Because the zone upon No.2 grade interface has identical lithology facies, the permeability is isotropic relatively.

No.3 grade interface: It forms at the stages of the minor flood which is located at the bottom erosion surface or at the stages of a sub-blood peak whose hydrodynamic condition varies, and it mainly develops in the point bar of a meandering river. Although the plugging action is similar to No.4 grade interface, its scale is smaller.

No.4 grade interface: In terms of the meandering river point sandbar, it forms at the bottom erosion surface in the deluge. It is the main stage of erosion concave and increasing convex in process of meandering river development. Its main body is the host lateral accretion of the crescent shape formed at the bottom erosion surface in the deluge. The inner seepage permeability is controlled by the properties of matter and distribution of space of thin interlayer.

No.5 grade interface: It is a complex of the sand interface. It generally shows smoothness or a little fovea. The basal lag gravel, partial incision and filling are its identification mark. No.5 grade interface and the top interface of point sandbar reflect the three-dimensional outer geometrical morphology of the well-preserved single point sandbar. It is surrounded by floodplain mudstone and forms a relatively independent oil-water carrying-gathering unit.

Previous researches of the architecture of interlayer mainly adopt some methods and techniques including abandoned surface of channel techniques and two-ply well techniques (Ma Shizhong, 2003). Our investigation shows that the technique is quite fit for the architecture research in this paper. And this paper mainly adopts several methods as follows in brief.

\subsubsection{Paired Wells Used for the Interpretation of Obliquity}

In the aspect of determining the configuration interface inclination according to paired wells, Professor Ma Shizhong has done a lot of work in this area, and achieved considerable success (Ma et al., 2008), whose findings are: When paired wells (paired wells refer to two ports of well, the distance of which is less than $50 \mathrm{~m}$.) share the same interlayer, the obliquity of interlayer superface can be determined. The studied area contains many paired wells, such as B1-60-536well and B1-60-537well. Through measuring height difference and spacing of the two wells, the obliquity of configuration interface can be counted by geometry operational method (Figure 5). Referring to this theory, researchers manage to carry out its configuration interface inclination. 


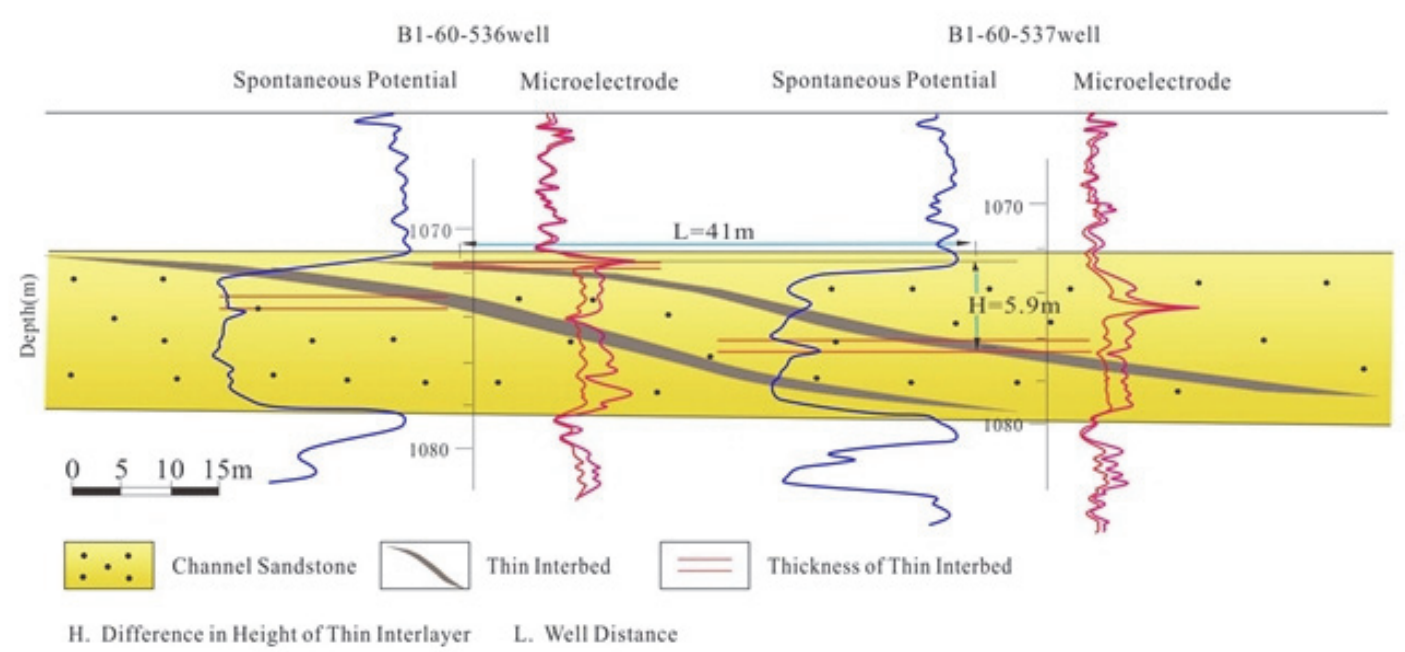

Figure 5. The dip angle is confirmed by the paired well of B1-60-536 and B1-60-537, the distance between the paired well is $41 \mathrm{~m}$ and the channel sandbody is determined by the logging curve as well as the cores data, then the thin interlays are also figured

The distance between B1-60-536 well and B1-60-537 well is only $41 \mathrm{~m}$, which extends from west to east approximately and is consonant with the direction of lateral accretion. At the two ports of well there is a $6.8 \mathrm{~m}$ thick and $7.5 \mathrm{~m}$-thick sandbody of meandering river respectively, and also a $0.25 \mathrm{~m}$ and $0.36 \mathrm{~m}$ intercalary stratum in the top and central section respectively at Putaohua oil layer formation PI2 individual reservoir. At the top of the two ports of well, there is a several-meter-thick interlayer according to the microelectrode curve. The thick interlayer, thick - thin interlayer, and thin interlayer are also identified in the channel, and every kind of interlayer has a good corresponding relation. Therefore, these should belong to the identical kind of deposition at the same time. In the meantime, the measured height difference is $59 \mathrm{~m}$, and consequently, the obliquity arctg $(5.9 / 41)$ is as follows.

$$
\operatorname{Arctg}(5.9 / 41)=\operatorname{arctg}(0.1439) \approx 8^{\circ} 11^{\prime}
$$

Because the direction of lateral accretion is identical with that of two ports of well connecting line, and the obliquity value basically accords with the numerical value interval range $\left(10 \sim 20^{\circ}\right)$ of the example Qianguo contemporary point bar (Dong Qingshui and so on, 1997) and the No.4 grade theoretical model of point bar, the obliquity can be regarded as a true value.

\subsubsection{Determine the Inclination of the Interface Configuration According to the Abandoned Surface}

The use of abandoned surface technology can also determine the configuration of the interface inclination(Ray \& Chakraborty, 2002; Ma, Sun, Fan, \& Hao, 2008; Shan, Zhang, et al., 2015). The abandoned surface is the lateral accretion sandbody superface of the last deposition in the abandoned channel. In essential, it is the last lateral surface of channel development. Hence, the obliquity of such an interface can be determined according to the abandoned surface. It is especially true when the abandoned surface is located on the beachhead or when two wells with a short distance touched the same abandoned surface.

Based on theoretical models of their researches, we have done configuration interface analysis of the B1-D4-P31 well, B1-D4-P32 well and B1-D4-P36 well. For example, the B1-D4-P31well is located on the point bar. The B1D4-P31well, the B1-D4-P32 well and the B1-D4-P36 well section pass through the abandoned channel by approximate northeast-east unfolding (Figure 6). The B1-D4-P32 well is located on the steep slope surface of the concave bank, and the B1-D4-P36 well is located to the ramp surface of the convex bank. The B1-D4-P31 well is filled with a complete (filling type) point bar, and the B1-D4-P32 well only $36.5 \mathrm{~m}$ apart from it is located in the central section of the abandoned channel. However, the B1-D4-P36 well is located on the margin of the abandoned channel. Consequently, the abandoned surface obliquity between B1-D4-P31well and B1-D4-P32 well is as follows.

$$
\operatorname{Arctg}(3.1 / 36.5)=\operatorname{arctg}(0.0849) \approx 4^{\circ} 51^{\prime}
$$

And the abandoned surface obliquity between B1-D4-P32 well and B1-D4-P36 well is as follows. 
$\operatorname{Arctg}(2.8 / 128.6)=\operatorname{arctg}(0.0218) \approx 1^{\circ} 15^{\prime}$

It is obvious that the obliquity value is too small and it is far less than the obliquity value $\left(10^{\circ} \sim 20^{\circ}\right)$ of Qianguo modern point bar( $\mathrm{Li}, 1996)$ and the theoretical model of point bar No.4 grade interface. Two main causes are as follows.

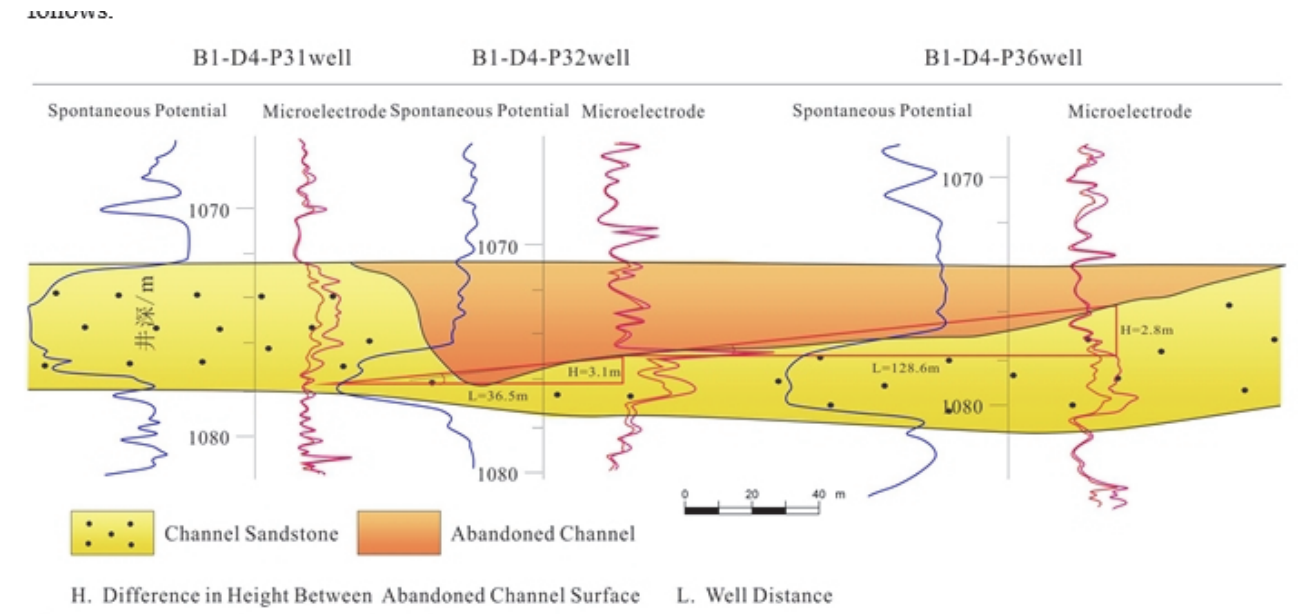

Figure 6. Through the horizontal and vertical difference values of the distance between the abandoned channel surface, the dip angle is confirmed by the abandoned channel surface

The abandoned channel is between the two wells. The obliquity of the abandoned surface will become smaller if the ligature of the superface of one complete point bar and the superface of the last lateral accretion sandbody of the other well is taken as the abandoned channel. To reduce the error, the data need adjusting in data processing. The result closest to the true obliquity can be obtained if the half of well spacing is taken as the borderline of the abandoned channel, especially when the well spacing is small. Accordingly, process (2) in the above can be calculated as follows.

$$
\operatorname{Arctg}[3.1 /(36.5 / 2)]=\operatorname{arctg}(0.1699) \approx 9^{\circ} 39^{\prime}
$$

The above obliquity is quite objective. Thus, the convex bank ramp obliquity of abandoned channel is as follows.

$$
\operatorname{Arctg}[2.8 /(128.6 / 2)]=\operatorname{arctg}(0.0435) \approx 2^{\circ} 30^{\prime}
$$

It is obvious that the small obliquity is caused by big well spacing. Therefore, the small well spacing is favorable for calculating the abandoned surface of the interlayer obliquity to avoid the error which comes from big well spacing.

When calculating the ramp obliquity of the convex bank, the data of one well reveals the central section of the abandoned channel, and the other the margin of the abandoned channel. The abandoned surface which comes from the superface of the last lateral accretion of the two wells is close to a plane, but in fact, the abandoned surface should be a concave which is gentle at the upper part, steep at the middle part and gentle at the lower part. There can exist a wide gentle slope close to the abandoned channel, especially close to its convex bank. Based on the above analysis, the obliquity recalculated according to the gentle slope close to the convex bank of the abandoned channel made up of B1-D4-P32well and B1-D4-P36 well belongs to this kind. In view of the error, it is suggested that the width of the abandoned channel be worked out and then positions of the steep zone of the concave bank and gentle slope of the convex bank be fixed before the obliquity of the abandoned surface is determined.

\subsubsection{Extraction of the Inclination of the Superface of the Thin Interlayer}

The methods are as follows:

1) Lateral accretion orientation is revealed through the horizontal distribution of the abandoned channel.

The lateral accretion orientation of meandering channel is always pointing to the direction of abandoned channel (Figure 7)(Ma et al., 2015; Shan, Li, et al., 2015). And its meandering ring is the best and full-scale proof which reveals the lateral accretion orientation of channel (see Meandering Ring in Figure 7. The meandering ring is the ring structure which comes forth due to the lateral accretion of the meandering channel). Thus here the distribution of meandering rings can be utilized to determine the accretion orientation of channel sandstones. There is a 
meandering ring at Ptutaohua oil layer formation PI2 individual reservoir, and the meandering ring where B1-60537 well is located shows extension of the lateral accretion is from east to west (northwest-west). Namely, along with the route from the B1-60-537well, B1-D4-P36 well to B1-D4-P31well, the lateral accretion tendency is $312^{\circ}$.

2) The abandoned surface determines the orientation of lateral accretion

Although some error occurs if the lateral accretion obliquity is determined by making use of abandoned surface in the case of very big well spacing, it can well reflect lateral accretion orientation, it is especially the case when the well-tie section is vertical to the abandoned channel and the penetration situation is at the margin or central section of the abandoned channel.

3) The tendency is determined according to the 3 wells with close well spacing

The lateral accretion orientation can be determined with the principle of "three-point forming a plane" when the penetration encounters the abandoned channel in the case of three wells or over with close well spacing.

\subsubsection{Extraction of the Scale of the Thin Interlayer Horizontal Distribution in Section}

According to the distribution of the plane graph (Figure 7), the abandoned channel width of large-scale meandering channel sandbody at Putaohua oil layer formation P I 2 individual reservoir is about $120 \mathrm{~m}$, and the lateral accretion width WL is about two-thirds of the river width.

$$
\mathrm{WL}=2 \mathrm{~W} / 3 \text { (Zhang \& Liu, 1997) }
$$

so,

$$
\mathrm{WL}=2 \mathrm{~W} / 3=2 \times 120 / 3=80 \mathrm{~m}
$$

Because the lateral mudstone usually lies on the top of lateral accretion and is easily eroded by the next flood, its width is usually smaller than that of the lateral accretion, and so the width of the maximum argillaceous thin interlayer is less than $80 \mathrm{~m}$.

\subsection{Space Conformation Establishment of Lateral Accretion Thin Mudstone Interlayer in Monosandbody}

Based on the above analysis, we can conclude that the Putaohua oil layer formation P I 2 individual reservoir in north No.1 and 2 line drilling well area in Daqing oilfield is meandering channel sandbody. On the plane of the meandering river, a broad complex meandering channel sandbody is formed due to repeated migration and pilingup in the way of lateral erosion and lateral accretion. In the sandbody, a lot of pinching zones and interstream sandbodies have developed, with a certain number of abandoned channels at its margin and in the interior. The sandbody width in the studied area is $1500 \mathrm{~m}$, the thickness is $4 \sim 8 \mathrm{~m}$, the channel width is $120 \mathrm{~m}$, the curvature is 1.73, the ratio of channel sandbody width and thickness is 150:200 and the meandering bandwidth/river width is 12.5. The close well spacings in the studied area are $100 \sim 200 \mathrm{~m}$. But they are still unable to define the margin of the channel. Thus, the channel width $\mathrm{W}$ may be estimated according to experience counting formula,

$$
\begin{aligned}
& \mathrm{W}=64.5 h^{1.54} \text { (Mu et al., 1998) } \\
& \text { ( } h \text { refers to sandbody thickness of channel) }
\end{aligned}
$$

Put the biggest thickness value of sandstone substitutes into the above formula, and the meandering river width can be determined. The architecture parameters of thin interlayer are as follows.

The lateral accretion orientation (tendency) is $115^{\circ}$; the obliquity values of different positions of the same lateral accretion are $20^{\circ}$ (middle part), $12^{\circ}$ (upper-middle part), $8^{\circ}$ (upper part) and $2^{\circ}$ (top) respectively, with an average $10.5^{\circ}$. The thickness of lateral argillaceous accretion interlayer is $30 \sim 80 \mathrm{~m}$. According to the above parameters, the architecture of thin interlayer can be restored in the monosandbody of the meandering channel (Figure 4). 


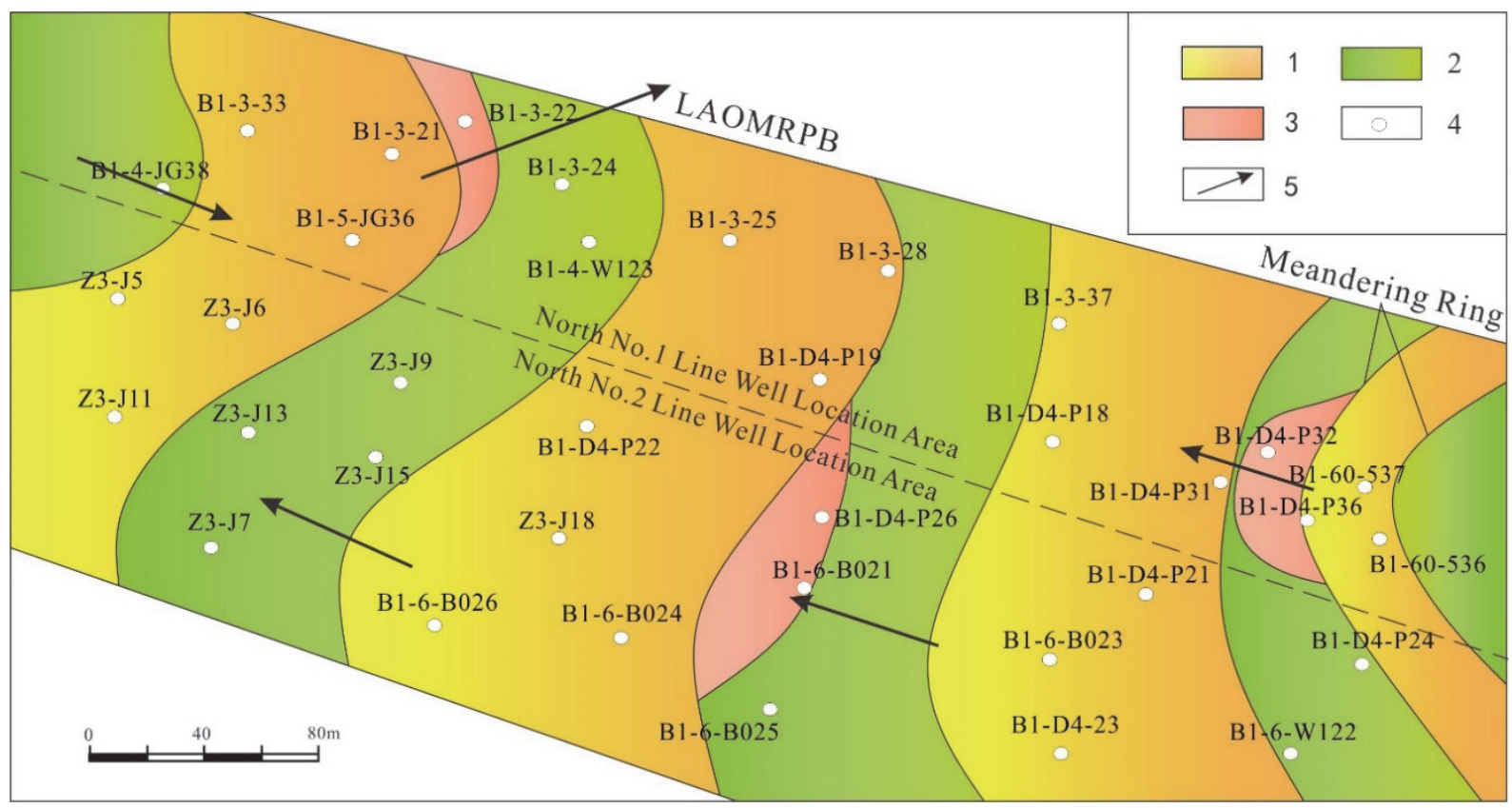

\section{Meandering Channel 2. Flood Plain Deposites 3. Abandoned Channel 4. Well Location}

\section{LAOMRPB-Lateral Accretion orient of Meandering River Point Bar}

Figure 7. The plane sedimentary micro-facies and the generalized geologic map of the region of interest at the $\mathrm{P}$

I 2 individual reservoir at the Putaohua reservoir formation in Daqing oilfield. With the evolution of meander rings, the lateral accretion orientation of meandering channel could be roughly identified, and the river morphology may also get a way to show itself

\section{Conclusion and Implications}

1) This thesis puts forward the categories, causes, and types of the thin interlayer, focusing on the importance of deposition and diagenesis of forming a thin interlayer. This thesis also states that the overwhelming majority of the thin interlayer in the studied area are caused through deposition, which is the dominant factor for forming thin interlayer in the studied area.

2) We have a preliminary research and discussion of thin interlayer three-dimensional configuration. The extraction of parameters of the monosandbody in the meandering river thin interlayer is the most important process. This thesis mainly discusses the determination of the obliquity of configuration interface by using the technique of paired wells and abandoned surface, i.e. to define the lateral accretion orientation through the plane distribution of abandoned channel, to work out the tendency through three wells with close well spacing, and to determine the scope of the horizontal distribution in thin interlayer section according to plane microfacies distribution. On this basis, the architecture of the interlayer is established.

3) Practice. According to the research findings, Daqing oilfield had better perfect PI2 individual reservoir well net, make full use of the potential oil layers and improve recovery ratio of ultra-high water-containing oil pool.

\section{Acknowledgments}

This study was financially supported by the National Natural Sciences Fund (No. 41372125) and Fund of Ministry of Education of Hubei Province (No. Q20121210), and the Ministry of Education key Laboratory on Tectonics and Petroleum Resources in China University of Geosciences (Wuhan) open foundation (TPR-2012-23).

\section{References}

Bjørlykke, K. (2014). Relationships between depositional environments, burial history and rock properties. Some principal aspects of diagenetic process in sedimentary basins. Sedimentary Geology, 301, 1-14.

Bjørlykke, K. (2015). Introduction to Petroleum. Geology Petroleum Geoscience (pp. 1-29), Springer.

Cui, J., Li, H., Feng, J., Liu, C., \& Ju, Y. (2013). Barrier - beds and inter - beds characteristics and their effects on remaining oil distribution in braided river reservoirs: A case study of the $\mathrm{Ng}$ IV oil unit in shallow north 
Gaoshangpu oilfield. Oilfield. Special Oil \& Gas Reservoirs, 20(4), 26-30.

Donselaar, M. E., \& Overeem, I. (2008). Connectivity of fluvial point-bar deposits: An example from the Miocene Huesca fluvial fan, Ebro Basin, Spain. Aapg Bulletin, 92(9), 1109-1129.

Dutton, S. P., Kim, E. M., Broadhead, R. F., Raatz, W. D., Breton, C. L., Ruppel, S. C., \& Kerans, C. (2005). Play analysis and leading-edge oil-reservoir development methods in the Permian basin: Increased recovery through advanced technologies. Aapg Bulletin, 89(5), 553-576.

Fabuel-Perez, I., Hodgetts, D., \& Redfern, J. (2009). A new approach for outcrop characterization and geostatistical analysis of a low-sinuosity fluvial-dominated succession using digital outcrop models: Upper Triassic Oukaimeden Sandstone Formation, central High Atlas, Morocco. Aapg Bulletin, 93(6), 795-827.

Fan, G., \& Ma, S. (2011). Fine Study of the Sedimentary Microfacies of Single Sand-body in Xing Twelve Area of Daqing Oilfield: Taking Important Sedimentary Time Units of Putaohua Oil-bearing Layer as an Example. Science Technology and Engineering, 11(7), 1535-1539.

Fu, G., \& Wang, Y. (2008). Oil Migration Transporting Pathways in Nose Structure Region outside Oil Source Area and Their Controlling on Oil Accumulation_Example of ShangJia region in the Songliao basin. Geological Review, 54(5), 646-652.

Fu, G., Lyu, Y., \& Fu, X. (2003). Evolutional stages of hydrocarbon concentration seal in mudstone caprocks. Chinese Journal of Geology, 32(2), 165-171.

Geehan, G., Lawton, T., Sakurai, S., Klob, H., Clifton, T., Inman, K., \& Nitzberg, K. (1986). Geologic prediction of shale continuity, Prudhoe Bay field. Reservoir characterization. LW Lake and HB Carroll Jr.(eds.). Academic Press, London, 63-82.

Gibling, M. R. (2006). Width and thickness of fluvial channel bodies and valley fills in the geological record: a literature compilation and classification. Journal of Sedimentary Research, 76(5), 731-770.

Hu, W., Lyu, B., Zhang, W., Mao, Z., Leng, J., \& Guan, D. (2005). An approach to tectonic evolution and dynamics of the Songliao Basin. Chinese Journal of Geology, 40(01), 16-31.

Labourdette, R., \& Jones, R. R. (2007). Characterization of fluvial architectural elements using a three-dimensional outcrop data set: Escanilla braided system, South-Central Pyrenees, Spain. Geosphere, 3(6), 422-434.

Le, Y., \& Wang, Y. (2002). Nonparametric regression applied in porosity parameter prediction. Chinese Journal of Geology, 37(01), 118-126.

Li, J., \& Liang, S. (2002). Mesozoic-Cenozoic Tectonic Features and Evolution of the Song-Liao Basin, NE China. Journal of Nanjing University (Natural Science), 38(4), 525-531.

Li, Q. (1996). Mode deposition and intra-formational anisotropic property of reservoir of clastic rock. Journal of Chengdu Institute of Technology, 23, 22-28.

Li, T., \& Luo, X. (2011). The inhomogeneity of petroleum migration in clastic carrier beds. Geological Review, $36(4), 402-413$.

Lin, Z. (2017). Channel planform migration architecture of meandering rivers. Journal of Geology \& Geophysics, 3(3). https://doi.org/10.4172/2381-8719-C1-009

Lin, Z., Shan, J., \& Chen, L. (2017a). Geomorphology Processes of Channel Planform Migration on Meandering Rivers. Acta Geographica Sinica (English Edition), 91, 134-135.

Lin, Z., Shan, J., \& Chen, L. (2017b). Meticulous Depiction and Genetic Mechanism of Unconformity Belt Structure. Earth Science Research, 6(2), 19. https://doi.org/10.5539/esr.v6n2p19

Liu, B., Zhang, G., Mao, F., Liu, J., \& Lü, M. (2017). Geochemistry and Origin of Upper Cretaceous Oils From the Termit Basin, Niger. Journal of Petroleum Geology, 40(2), 195-207.

Liu, K., Yang, X., \& Yang, C. (2004). Study of Reservoir Heterogeneity in the Second Sand Bodies of the Fourth Member of Shahejie Formation of Fault Block 81 in Dongpu Depression. Fault-block Oil \& Gas Field, 11(4), 55-57.

Lyu, X., Ma, F., \& Tian, D. (1994). A study of lithology, petro-physical of barrier beds and their distribution properties. Ptroleum Exploration and Development, 21(05), 80-88.

Ma, L. (1992). Sandstone oil-gas reservoir configuration analysis and application prospect. Natural Gas Earth Science, 3(02), 11-16. 
Ma, S., Niu, D., Zeng, B., Zhang, J., Zhang, Y., \& Dong, Y. (2015). Provenance analysis on Putaohua reservoir in Puxi oilfield's G1 region, Daqing. Journal of Heilongjiang University of Science and Technology, (5), 531536.

Ma, S., Sun, Y., Fan, G., \& Hao, L. (2008). The Method for Studying Thin Interbed Architecture of Burial Meandering Channel Sandbody. Acta Sedimentologica Sinica, 26(4), 632-639. http://dx.doi.org/10. 14027/j.cnki. cjxb.2008. 04.013

MacDonald, A. C., \& Halland, E. K. (1993). Sedimentology and shale modeling of a sandstone-rich fluvial reservoir: Upper Statfjord Formation, Statfjord Field, Northern North Sea. Aapg Bulletin, 77(6), 1016-1040.

Mackey, S. D., \& Bridge, J. S. (1995). Three-dimensional model of alluvial stratigraphy: theory and application. Journal of Sedimentary Research, 65(1).

Matapour, Z., \& Karlsen, D. (2017). Geochemical Characteristics of The Skrugard Oil Discovery, Barents Sea, Arctic Norway: A "Palaeo - Biodegraded - Gas Reactivated" Hydrocarbon Accumulation. Journal of Petroleum Geology, 40(2), 125-152.

Miall, A. D. (1988). Architectural elements and bounding surfaces in fluvial deposits: anatomy of the Kayenta Formation (Lower Jurassic), southwest Colorado. Sedimentary Geology, 55(3-4), 233247-240262.

Miall, A. D. (2014). Fluvial depositional systems (Vol. 14): Springer.

Morad, S., Al-Ramadan, K., Ketzer, J. M., \& De Ros, L. (2010). The impact of diagenesis on the heterogeneity of sandstone reservoirs: A review of the role of depositional facies and sequence stratigraphy. Aapg Bulletin, 94(8), 1267-1309.

Mu, L., Ja, A., Huang, S., Chen, L., Chen, J., \& Li, P. (1998). Synthesize research of fluvial-delta reservoir outcrop and contemporary fluvial sediments. Beijing: Scientific Research Institute of Petroleum Exploration \& Development.

Ray, S., \& Chakraborty, T. (2002). Lower Gondwana fluvial succession of the Pench-Kanhan valley, India: stratigraphic architecture and depositional controls. Sedimentary Geology, 151(3), 243-271.

Ru, Y., He, S., \& Zhou, X. (2016). The research of flow unit remaining oil distribution of ultral-low permeability reservoir. Inner Mongolia Petrochemical Industry, (01), 127-130.

Shan, J., Li, Z., Ge, X., Zhang, Y., Cui, L., Chong, J., ... Jiang, L. (2015). A method of reconstructing evolutionary process of meandering channel in Paleo-sedimentary period. Journal of China University of Mining \& Technology, 44(5), 843-852.

Shan, J., Zhang, J., Zhao, Z., Li, F., Sun, L., Zhang, B., \& Fang, S. (2015). Analysis of sedimentary and evolution process for underground meandering river point bar: a case study from No.23 thin layer of Yangdachengzi oil reservoir in Jilin oilfield. Acta Petrolei Sinica, 36(7), 809-819. https://doi.org/10.7623/syxb201507005

Singh, K., Bijeljic, B., \& Blunt, M. J. (2016). Imaging of oil layers, curvature, and contact angle in a mixed - wet and a water - wet carbonate rock. Water Resources Research.

Wang, G., \& He, G. (1995). Distribution of the intercalations in thick reservoirs, Shuanghe oilfields. Ptroleum Exploration and Development, 22(2), 55-59.

Wang, J., Xu, S., \& Zhong, W. (2010). Genesis and Distribution of the Interlayer in Fluvial Reservoir. Geological Science \& Technology Information, 29(4), 84-88.

Wu, S., \& Yue, D. (2008). Study on the hierarchical modeling of the reservoir structure of the underground river. Scientia Sinica (Terrae)(S1), 114-124.

Wu, X., Hou, J., Wang, D., Cui, Z., \& Shuqing., L. (2014). New Calculation Method for Interlayer Dip and Its Application in Beach-bar Sand Mud Interlayer Depiction. Science \&Technology Review, 12, 48-53.

Xue, P. (1991). An introduction to reservoir models of point bar facies. Beijing: Petroleum Industry Press.

Yang, X. F., Xie, Y. F., Zhang, Z. W., Ma, Z. Z., Zhou, Y. B., Liu, Y. M., ... Zhao, Y. B. (2017). Hydrocarbon Generation Potential and Depositional Environment of Shales in the Cretaceous Napo Formation, Eastern Oriente Basin, Ecuador. Journal of Petroleum Geology, 40(2), 173-193.

Ye, D. (2005). Lower Cretaceous sequence stratigraphic framework and hydrocarbon accumulation in the Southeast Rise, Songliao basin, China. Chinese Journal of Geology, 40(02), 227-236.

Zhang, C., \& Liu, Z. (1997). Contemporary river-lake sediments and simulation experiment. Beijing: Petroleum 
Industry Publication.

Zhang, C., Yin, T., Yu, C., Ye, J., \& Du, Q. (2013). Reservoir architectural analysis of meandering channel sandstone in the delta plain based on the depositional process. Acta Sedimentologica Sinica, 31(4), 653-662.

Zhang, J., \& Zhang, L. (2003). The Genesis and Characteristics and Identification of Intercalations in Non-marine Reservoir of Clastic Rock. Well Logging Technology, 27(3), 221-224.

Zhang, Y. (2004). Study of fluvial sandbody architecture in north1-2 area of saertu oil fields. Daqing Petroleum Institute.

Zhao, H. (2002). Approach to the study thinking about reservoir heterogeneous system: sandbody internal construction structure and flow unit. Petroleum Geology \& Experiment Development Daqing, 21(06), 16-19.

Zhao, J., Xu, H., Xu, Z., Wei, Q., Guo, D., Liu, Y., \& Yang, H. (2016). Controlling mechanism on remaining oil distribution by development fluid potential in middle-high permeability reservoir. Journal of China University of Mining \& Technology, 45(3), 535-543.

Zhong, D., \& Zhu, X. (2008). Characteristics and genetic mechanism of deep-buried clastic eureservoir in china. Science in China Series D: Earth Sciences, 51(S2), 11-19.

\section{Copyrights}

Copyright for this article is retained by the author(s), with first publication rights granted to the journal.

This is an open-access article distributed under the terms and conditions of the Creative Commons Attribution license (http://creativecommons.org/licenses/by/4.0/). 